\title{
CAO YANG
}

Uniwersytet Jagielloński w Krakowie

ORCID: https://orcid.org/0000-0001-6365-7817

PaWEŁ PŁAneta

Uniwersytet Jagielloński w Krakowie

ORCID: https://orcid.org/0000-0001-9757-9570

\section{"The Gateway to Europe". The Discourse on Poland in the Chinese Press (2015-2020)}

\section{"The Gateway to Europe". The Discourse on Poland in the Chinese Press (2015-2020)}

\section{Abstract}

The aim of the article is to present the results of the survey on the structure of the discourse on Poland present in the content of various Chinese newspapers and magazines. In the first part, we provide an overview of the history, characteristic and development trends of the Chinese newspaper market. In order to construct the collection of messages about Poland and Poles, a query was carried out in 172 journalistic materials published in 2015-2020. The first step of analysis performed in this research was the lexical analysis of the Chinese print media gathered in the text corpus of app. 160 thous. words. Additionally, the authors of the article used text mining analytics software to extract the main concepts. The next phase of the survey was the computer assisted content analysis. For the research purposes 150 categories dictionaries were created. Those dictionaries consisted of the set of words gathered on the same semantic basis. The unit of the analysis in this phase of the research was a single paragraph ( $\mathrm{N}=2465$ units) and the results of this analysis were the hierarchy and key-ness of collective symbols, themes, actors and places present 
in the press discourse on Poland. In the last part of the research-as a result of factor analysis - the structure of the discourse on Poland in the Chinese press was reduced to 9 strongest factors determining which different (detailed) categories have the tendency to co-occur and that is why they create easily distinguishable configurations.

Keywords: press image of Poland, discourse, foreign news, content analysis, Chinese press

\section{Ворота в Европу. Дискурс о Польше в китайской прессе (2015-2020)}

\section{Аннотация}

Цель статьи - представить результаты исследования структуры дискурса о Польше, присутствующего в содержании различных китайских газет и журналов. В первой части сделан обзор истории, характеристик и тенденций развития китайского газетного рынка. Для подборки сообщений о Польше и поляках был проведен анализ 172 публицистических материалов, опубликованных в 2015-2020 годах. Первым шагом в данном исследовании стал лексический анализ китайских печатных СМИ, собранных в текстовом корпусе приложения, содержащего 200000 слов. Кроме того, для анализа текстов авторы статьи использовали программное обеспечение для извлечения основных концепций. Следующим этапом исследования стал компьютерный контент-анализ. Для исследовательских целей создано 150 категорий словарей. Эти словари состояли из набора слов, собранных на одной семантической основе. Единицей анализа на этом этапе исследования был отдельный абзац ( $\mathrm{N}=2465$ единиц), а результатом - иерархия и значимость коллективных символов, тем, актеров и мест, присутствующих в печатном дискурсе относительно Польши. В последней части исследования - при помощи факторного анализа - структура дискурса о Польше в китайской прессе была сведена к 9 сильнейшим факторам, определяющим, какие различные (детализированные) категории имеют тенденцию к совместному появлению и именно поэтому создают легко различимую конфигурацию.

Ключевые слова: образ Польши в прессе, дискурс, зарубежные новости, контентанализ, китайская пресса

\section{Introduction}

W ith the process of reform and opening up, China's economic and social development has made remarkable achievements around the world. As the world's second largest economy, China has become a leading force 
in global multilateral governance by advocating and advancing the global development agenda in the world's major multilateral arenas and continuing its efforts to promote international cooperation. 2018 saw China’s diplomacy raise the banner of multilateralism and move forward from following the trend to acting on it. Among them, the "Belt and Road" initiative proposed by President Xi Jinping in 2013 became an important link for China to expand its international "circle of friends". Since the official introduction of the " $16+1$ " cooperation framework in 2015, the CEE region has gradually moved from being a peripheral area of cooperation with China to the center of attention, and Poland, as the "leader" of the region, is often mentioned in the Chinese media as "the gateway to Europe".

The main aim of this article is to present the results of the survey on the discourse on Poland present in the Chinese press in the years 2015-20202. We define the term "discourse" as a process of creating, strengthening and disseminating the system of social meanings, whose recognition takes place mainly owing to the analysis of its elements, which refer to texts of their social backgrounds i.e. discourse participants (partners) $)^{3}$. So the discursive

${ }^{1}$ Over the past five years, policy-driven cooperation between China and Poland has increased significantly in various fields, with bilateral trade almost doubling (from \$17.01 billion in 2015 to $\$ 31.06$ billion in 2020), and local cooperation and humanistic exchanges becoming more solid and deeper. During this period, cooperation between the two sides has had its share of win-wins and setbacks, and by understanding how Poland is portrayed in the Chinese media, the groundwork can be laid for further, more precise and complementary cooperation. See: Ministry of Foreign Affairs of the People's Republic of China. (2021, Jul.) Relations between China and Poland. Retrieved from www.fmprc.gov.cn/web/gjhdq_676201/ gj_676203/oz_678770/1206_679012/sbgx_679016/. For more information about China's diplomacy and country's development during Xi Jinping's presidency see: Góralczyk, 2017; Góralczyk, 2018; Kupś et al., 2021; Marszałek-Kawa, 2014; Marszałek-Kawa, Dmochowski, 2018.

2 Press materials from 2015-2020 were selected for the study due to the fact that the period of consolidation of right-wing governments in Poland also saw an intensification of the Polish-American relations and the resulting potential problems in Warsaw's cooperation with Beijing, which - as assumed - was an important mechanism of media framing of journalistic coverage of Poland in the Chinese press. At the same time, the period of analysis was chosen due to the emergence of the "Belt and Road" initiative in 2015, and hence Beijing's strategy covers the Central Europe and pays more attention to the situation and development of the society in Poland.

3 In linguistics, theoretical sources of the term 'discourse' can be detected in accomplishments of linguists, representatives of American Structural Linguistics (e.g. Franz Boas, 
image of a certain country in the media is an important indication of its soft power. Because of that it is worth analyzing how Poland is perceived and how its image changes over time. The Chinese media are not a popular subject among Polish media experts despite the fact that Polish-Chinese relations have a long history. This article tries to answer the following questions: Is Poland a recurring topic in the Chinese press? How is it perceived and what are the most important stories covered? We will also try to find out if that image changes and what factors influence it. While looking for the answers to the research questions, we used triangulation of methods to help us eliminate mistakes with statistics interpretation and to avoid heuristic observations. We have analyzed the corpus of texts ${ }^{4}$ that appeared in the leading Chinese newspapers - frequency lists, used factor analysis, computer content analysis and finally qualitative research. Before we start the direct research we should understand the environment in which these articles were published.

Edward Sapir, Leonard Bloomfield) and their followers (e.g. Zellig S. Harris). Linguistic analysis, according to their approach, consisted in studying the surrounding contexts in which a given linguistic element appeared. Discourse analysis is a method of seeking in any connected discrete linear material, whether language or language-like, which contains more than one elementary sentence, some global structure characterizing the whole discourse (the linear material), or large sections of it. The concept of discourse analysis turned toward the idea of searching for structure, i.e. 'patterns of co-occurrence'. According to this method, at the beginning the number of regularly occurring elementary units of discourse were counted (by the use of the so-called segmentation procedure of words, parts of words, phrases, expressions), then the units were classified and the rules governing the ways of joining them were searched for. Distributional discourse analysis recognizes the semantic meaning of words, taking into consideration only their surroundings, the occurrence of other text units, e.g. other words or parts of words. The feature which distinguishes discourse - according to narrative theory - refers to the manifestation of the 'speaking' subject and the relation taking place between the subject and audience. Regarding the social aspect, in the most general terms we have to do with 'discourse' when people use the language to describe, understand or change the world surrounding them. The term 'discourse' functions similarly in philosophy, e.g. in works of Frankfurt School where 'discourse' refers to such a type of communication by means of which people communicate with each other on the subject of important rules and norms of public life.

4 All of the newspaper texts analyzed in this article were published in Chinese. However, for the purposes of the quantitative linguistic analyses in this project, they were translated into English. DeepL Pro software was used in the translation process. The accuracy of the translation was thoroughly checked by Cao Yang as a Chinese-speaking person. 


\section{An overview of China's newspaper industry}

Chinese newspapers, which have been established and developed almost in parallel with China's modernization process, have borne witness to the most important transformations of the Chinese society over the past two centuries. Since 1815, when the first Chinese-language newspaper, Chinese Monthly Magazine (《察世俗每月统纪传》Cha Shisu Meiyue Tongji Zhuan), a religious newspaper founded by foreign missionaries, was published, for over 200 years the newspaper has been one of the elite media in China, shaping social reality and constructing the way modern Chinese people think and live.

Over the past 50 years, the development of China's newspaper industry in line with social change and economic progress can be divided into 3 stages. From the early 1950s to the early 1980s, in the social surrounding of the planned economic system dominated ideologically-oriented "party newspapers", which presented serious but dull political issues. From the mid-1980s to the 1990s, the evening newspapers catered to more ordinary people with "soft" content rather than general propaganda. In the mid-1990s, the metropolis Daily, namely "popular newspapers", headed up the industry (Hu, 2009). At the beginning of the 21st century, so called new mainstream newspapers, such as political newspaper Global Times (《环球时报》Huanqiu Shibao), financial ones Economic Observer (《经济观察报》Jingji Guancha Bao) and The 21st Century Business Herald (《21世纪经济报道》21 Shiji Jingji Baodao) began to emerge and gain popularity.

Since 1968 (186 titles) to 2007 (1926 titles) the number of newspapers in China increased tenfold. Since 2002, China had been the world's number one market for daily newspapers, and in 2004 it was number one in the world with 93.5 million copies sold daily, followed by India, Japan, the USA and Germany (Deng, 2018). Advertising revenue also doubled from 2001 to 2006. However, with the subsequent proliferation of other news sources, newspaper circulation and advertising in China has fallen sharply year by year since 2012 .

As of December 2019, China had a total of 1,851 newspapers, and 10,171 magazines. Compared to the previous year, the number of newspapers decreased by $1.07 \%$, and the total number of copies printed decreased by $5.83 \%$. The number of journal titles increased by $0.32 \%$, and the average print run 
per issue decreased by 3.34\%. Currently, Chinese newspapers are divided into 5 categories based on their topics: general newspapers (party newspapers and metropolis newspapers), specialized newspapers, life services newspapers, reader-targeted newspapers, and press reviews. In 2019, there were 857 general newspapers, 667 specialized newspapers, 203 life services newspapers, 102 reader-targeted newspapers and 22 press reviews in China.

Table 1. Classification of newspapers by subject matter ${ }^{5}$

\begin{tabular}{|l|c|c|c|c|l|}
\hline Subject matter & $\begin{array}{c}\text { Circulation } \\
\text { (in million } \\
\text { copies) }\end{array}$ & Change & $\begin{array}{c}\text { Market } \\
\text { share }\end{array}$ & Trend & \multicolumn{1}{|c|}{ Newspapers } \\
\hline $\begin{array}{l}\text { General } \\
\text { newspapers }\end{array}$ & 194.95 & -7.33 & $61.38 \%$ & -0.99 & $\begin{array}{l}\text { People's Daily, } \\
\text { Guangming Daily }\end{array}$ \\
\hline $\begin{array}{l}\text { Specialized } \\
\text { newspapers }\end{array}$ & 98.67 & -1.34 & $31.07 \%$ & 1,41 & $\begin{array}{l}\text { China Business } \\
\text { News, China } \\
\text { Metallurgical } \\
\text { News }\end{array}$ \\
\hline $\begin{array}{l}\text { Life services } \\
\text { newspapers }\end{array}$ & 5,92 & -25.61 & $4.79 \%$ & -0.5 & $\begin{array}{l}\text { Jin Bao, Cangzhou } \\
\text { TV News }\end{array}$ \\
\hline $\begin{array}{l}\text { Reader-targeted } \\
\text { newspapers }\end{array}$ & 15.21 & -2.1 & $1.86 \%$ & 0.18 & $\begin{array}{l}\text { China Women's } \\
\text { News }\end{array}$ \\
\hline Press reviews & 2.84 & -16.22 & $0.90 \%$ & -0.11 & Writter's Digest \\
\hline
\end{tabular}

Source: Basic information on the national press and publishing industry in 2019. For details see: State Press and Publication Administration (2020, Sep.).

In 2019, a total of 20 newspapers, including People’s Daily (《人民日 报》Renmin Ribao), Cankao Xiaoxi (《参考消息》), and Global Times (《环球时报》Huanqiu Shibao), had an average circulation of 1 million or more issues, 2 more than in 2018; 5 of them are general newspapers, 13 are specialized newspapers (including 11 in the teaching and guidance category), and 2 are destination newspapers for readers.

${ }^{5}$ Newspapers title mentioned in the table: People's Daily (《人民日报》Renmin Ribao); Guangming Daily (《光明日报》Guangming Ribao); China Business News (《第一财经日 报》Diyi Caijing Ribao); China Metallurgical News (《中国冶金报》Zhongguo Yejin Bao); Jin Bao (《近报》Jin Bao); Cangzhou TV News (《沧州广播电视报》Cangzhou Guangbo Dianshi Bao); China Women's News (《中国妇女报》Zhongguo Funv Bao); Writter's Digest (《作家文摘》Zuojia Wenzhai) 
Table 2. Top 10 general interest newspapers by average circulation in 2019

\begin{tabular}{|c|l|c|l|l|}
\hline Rank & \multicolumn{1}{|c|}{ Title } & $\begin{array}{c}\text { Number of } \\
\text { editions (weekly) }\end{array}$ & \multicolumn{1}{|c|}{ Region } & \multicolumn{1}{|c|}{$\begin{array}{c}\text { Rank in } \\
\mathbf{2 0 1 8}\end{array}$} \\
\hline 1. & People's Daily & 7 & Beijing & 1 \\
\hline 2. & CanKao Xiaoxi & 7 & Beijing & 2 \\
\hline 3. & Xinhua Daily Telegraph & 7 & Beijing & 3 \\
\hline 4. & Guangming Daily & 7 & Beijing & 7 \\
\hline 5. & Global Time & 6 & Beijing & 5 \\
\hline 6. & South Daily & 7 & Guangzhou & 8 \\
\hline 7. & Economic Daily & 7 & Beijing & 9 \\
\hline 8. & Peninsula city newspaper & 6 & Shan dong & 6 \\
\hline 9. & City Express & 7 & Zhe jiang & 10 \\
\hline 10 & Qianjiang Evening News & 7 & Zhe jiang & 11 \\
\hline
\end{tabular}

Source: Basic information on the national press and publishing industry in 2019. For details see: State Press and Publication Administration (2020, Sep.).

The Chinese characteristics of the newspaper industry are about that after successive adjustments, the structure of China's newspapers has gradually formed a structure in which the party newspaper is the core, and metropolis, specialized and other types of newspapers are developed together, and that most of the newspapers are aimed at being mainstream media. The newspaper industry is moving towards marketisation, conglomeration and integration with new media.

Party newspapers which are perceived as opinion leaders, i.e. defined as the organ of the Communist Party of China, are a distinctive political-cultural phenomenon in contemporary China. They are regarded as the voice of the government and the tools for propagating the program, line and policy of the party, which to a large extent play a decisive role in setting news agenda, engaging in hot issues, shaping mainstream values and broadcasting major events. However, this does not mean that their coverages are all positive when it comes to the Communist Party, as the function of "monitoring public opinion" has been stressed by the leaders since the publication of the party newspaper. Efforts are also designed to reveal government scandals and wrong doings.

In the 21st century the trend of being mainstream newspapers is the goal that most Chinese dailies strive for. According to researcher Lv Shangbin's 
analysis, the four main strategic directions for newspapers to transform into Mainstream Media are: being people-oriented, industrialization, digitalization and internationalization (Lv, 2011). These types of newspapers are intended to be the source of information and ideas that mainstream society relies on. In addition, they are characterized by wide distribution, high credibility, and are not evaluated on the basis of the amount of revenue generated. As all newspapers in China are owned by the state, Chinese authorities still encourage newspapers to enhance their market-driven capacity to grow bigger and stronger. Reorganizing all the newspapers in groups is one of the efforts.

It has been 23 years since the first Chinese newspaper group, Guangzhou Daily Newspaper Group, was founded in 1996. To date, forty-five newspaper groups were approved by the State Administration of Press, Publication, Radio, Film and Television. These newspaper groups are located in different places of China and represent the highest level of development of the Chinese newspaper industry.

Table 3. Top 10 newspaper publishing groups in comprehensive assessment of overall economic scale ${ }^{6}$

\begin{tabular}{|c|l|l|l|}
\hline Rank & Title & Ratings & Example \\
\hline 1. & Shanghai United Media Group & 3.72 & Shanghai Daily, Xinmin Evening News \\
\hline 2. & Zhejiang Daily Press Group & 3.25 & Media Review, Zhejiang Daily \\
\hline 3. & Hubei Daily Media Group & 1.76 & Hubei Daily, Chutian Metro, Jianghan Daily \\
\hline 4. & Chengdu Media Group & 1.4 & Chengdu Daily, Chengdu Evening News \\
\hline
\end{tabular}

${ }^{6}$ Shanghai Daily (《上海日报》Shanghai Ribao); Xinmin Evening News (《新民晚报》 Xinmin Wanbao); Media Review (《传媒评论》Chuanmei Pinglun); Zhejiang Daily (《浙江 日报》Zhejiang Ribao); Hubei Daily（湖北日报》Hubei Ribao);Chutian Metro (《楚天都 市报》Chutian Dushibao); Jianghan Daily (《江汉日报》Jianghan Ribao); Chengdu Daily (《成都日报》Chengdu Ribao); Chengdu Evening News (《成都晚报》Chengdu Wanbao); Henan Daily (《海南日报》Hainan Ribao), Henan Legal News (《大河法制报》Dahe Fazhibao); Guangzhou Daily (《广州日报》Guangzhou Ribao); World Review (《看世界》 Kanshijie); Information Times (《信息时报》Xinxi Shibao); Dazhou Daily (《达州日报》 Dazhou Ribao); Dazhou Radio and Television News (《达州电视广播报》Dazhou Dianshi Guangbo Bao); Xinhua Daily (《新华日报》Xinhua Ribao); Yangzi sports (《扬子体育报》 Yangzi Tiyubao); Jiangsu Legal system (《江苏法制报》Jiangsu Fazhibao); Shenzhen Evening News (《深圳晚报》Shenzhen Wanbao); Shenzhen Commercial Daily (深圳商业日报》 


\begin{tabular}{|c|l|l|l|}
\hline Rank & Title & Ratings & Example \\
\hline 5. & Henan Daily Press Group & 0.94 & Henan Daily, Henan Legal News \\
\hline 6. & Guangzhou Daily Press Group & 0.83 & $\begin{array}{l}\text { Guangzhou Daily, World Review, Informa- } \\
\text { tion Times }\end{array}$ \\
\hline 7. & $\begin{array}{l}\text { Shandong Dazhou Press Co. } \\
\text { Ltd. }\end{array}$ & 0.8 & $\begin{array}{l}\text { Dazhou Daily, Dazhou Radio and Televi- } \\
\text { sion News }\end{array}$ \\
\hline 8. & Jiangsu Xinhua Media Group & 0.74 & $\begin{array}{l}\text { Xinhua Daily, Yangzi sports, Jiangsu Legal } \\
\text { system }\end{array}$ \\
\hline 9. & Shenzhen Press Group & 0.73 & $\begin{array}{l}\text { Shenzhen Evening News, Shenzhen Com- } \\
\text { mercial Daily }\end{array}$ \\
\hline 10. & Nanfang Daily Media Group & 0.66 & Nanfang Daily, Nanfang Metro \\
\hline
\end{tabular}

Source: Basic information on the national press and publishing industry in 2019. For details see: State Press and Publication Administration. (2020, Sep.)

However, as the newspaper groups are arranged by administration of government rather than by market force, some of them turned out to be a cluster of similar newspapers without apparent reason to cooperate. One of the largest causes of such kind of failure is the dual-track system.

The Chinese newspaper industry can be perceived as the dual-track system. It is part of the nation's propaganda mechanism, but it is operated as an enterprise which may be run in the most profitable way to earn the most revenue instead of depending on government subsidies. However, the organization structure as an organ of the government has played a restraining role in many aspects including newspapers' consolidation and marketization. Therefore, in 2009 the National Press and Publication Administration of China began to implement pilot transformation for all levels of newspapers.

From the "Guiding Opinions on Promoting the Integrated Development of Traditional Media and Emerging Media" approved at the fourth meeting of the Central Steering Group on Comprehensive Deepening Reform in August 2014 to the "Opinions on Acceleration on Development of Deepened Media Integration" in September 2020, from "promotion", "convergence" to

Shenzhen Shangye Ribao; Nanfang Daily (《南方日报》Nanfang Ribao); Nanfang Metro (《南方都市报》Nanfang Dushibao). 
"acceleration" and "deep integration", the development of media convergence in China has entered a new stage.

\section{An overview of Poland coverage in the Chinese media in comparison to other countries}

Poland does not appear very frequently in the Chinese press, with coverage of Poland mainly concentrated in major national newspapers such as People's Daily (Guangming Daily (《光明日报》Guangming Ribao), Xinmin Evening News (《新民晚报》Xinmin Wanbao), Global Times and Cankao Xiaoxi.

The headlines, leads and crucial parts of the journalistic materials ${ }^{7}$ devoted to Poland in Chinese national newspapers cover four themes, mainly economy, politics, culture, and tourism, which to some extent guide the local newspapers when it comes to topics and attitudes.

Table 4. The rank of countries appearing in the 3 China dailies

\begin{tabular}{|c|l|r|l|l|l|r|}
\hline Rank & \multicolumn{2}{|l|}{ People's Daily (2015-2020) } & $\begin{array}{l}\text { Economic Daily } \\
\text { (2015-2020) }\end{array}$ & \multicolumn{2}{|l|}{ Global Times (2018-2020) } \\
\hline 1 & USA & 17824 & USA & 859 & USA & 488 \\
\hline 2 & Japan & 8405 & Japan & 387 & England & 248 \\
\hline
\end{tabular}

${ }^{7}$ Headlines and leads play a special role in the content of the print media. Undoubtedly, they create-especially in the news press-clear arrangements of content that are hierarchically organized: from the most important material to journalistic statements of lesser importance. Thus, headlines provide empirically accessible evidence of the operation of selection mechanisms in the press, both the results of editorial selection, i.e. the decision of which events-due to their informational value in the opinion of the editors-deserve to be disseminated, and the agenda built on the hierarchy of importance of events. A print newspaper operates in a sequential manner: from the most important (on the "front page" of the newspaper, as well as in the first columns of local mutations and thematic supplements) to additional materials, etc. Such organization of the content strengthens the effect of establishing the "agenda" and leads to the creation of a framework for interpretation and a specific narrative: it creates ways of understanding events and disseminates specific journalistic stories about the reality. The reader of the press, on the basis of reading only the headlines, may have the impression of a picture of the whole, because the headlines, thanks to their organization, conciseness and attractiveness, effectively attract the attention of the recipient and effectively influence even those readers who have less and less time to read the newspaper. 


\begin{tabular}{|c|l|r|l|r|l|r|}
\hline Rank & \multicolumn{2}{|l|}{ People's Daily (2015-2020) } & $\begin{array}{l}\text { Economic Daily } \\
(2015-2020)\end{array}$ & \multicolumn{2}{l|}{ Global Times (2018-2020) } \\
\hline 3 & Russia & 7595 & England & 280 & Germany & 122 \\
\hline 4 & England & 7291 & Germany & 276 & Japan & 91 \\
\hline 5 & Germany & 6975 & France & 255 & Russia & 87 \\
\hline 6 & France & 5929 & Republic of Korea & 198 & Republic of Korea & 85 \\
\hline 7 & Republic of Korea & 4163 & Russia & 192 & France & 84 \\
\hline 8 & Italy & 2862 & Greece & 92 & Italy & 32 \\
\hline 9 & Poland & 1266 & Hungary & 77 & Poland & 10 \\
\hline 10 & Greece & 1266 & Italy & 51 & Austria & 8 \\
\hline 11 & Czech Republic & 776 & Austria & 22 & Greece & 5 \\
\hline 12 & Austria & 771 & Poland & 20 & Czech Republic & 5 \\
\hline 13 & Hungary & 748 & Czech Republic & 13 & Hungary & 5 \\
\hline
\end{tabular}

Own elaboration. Data Source: China National Knowledge Infrastructure, Baozhi Shujuku 报纸数据库 [Newspaper database]. Retrieved from: http://gb.global.cnki.net/kns/ brief/result.aspx?dbPrefix=CCND.

Poland's image in the Chinese media is generally positive. In the economic field, Poland has been the "leader" in Central and Eastern Europe since the economic transition, and since the implementation of the "Belt and Road" initiative, China-Poland economic and trade cooperation has been fruitful. In the political sphere, the focus was on Poland's international relations, mainly with the US, Russia and China, as well as international organizations such as the EU and $\mathrm{NATO}^{8}$. In the cultural sphere, the development and status of Polish literature, history, theatre and music are enduring topics. In the area of tourism, Poland's natural resources and deep-rooted human environment are constantly highlighted in the Chinese press. Local newspapers focus on culture, tourism, politics and cooperation with China, with topics similar to those in the national press. In the Chinese press-in axiological dimension-Poland's sense of apprehension about territorial security issues has

8 The countries that often appear in the report all intersect with Poland in the historical dimension. For example, each of Germany, Russia and France had a match or alliance with Poland in World War II. France and Italy were even the inspiration for several Polish artists and scientists. Once again, this confirms the Chinese media's special interest in Polish history and the development of Polish culture. The major tourist cities in Poland are more frequently reported in the Chinese media. 
increased after several demises of independence, and its citizens are generally rebellious, they pursue and cherish freedom and value humanism in society. The country's difficult destiny has become a source of artistic creation and emotional expression. The active development and transmission of the best national culture, represented by literature, has given the whole country an artistic flavor. The key values in the discourse on Poland in the Chinese press are beauty and love.

\section{The main hypothesis and methodology of research}

In order to discover the main elements of the discursive image on Poland present in the Chinese press in the years 2015-2020 the multi-step analysis was conveyed.

The first step of the analysis performed in this research was the lexical analysis of the Chinese newspaper content gathered in the text corpus. The results of statistical evaluations were the words frequency lists which were used for the analysis of certain words concordances and collocations. The effect of such procedure was the reconstruction of important words co-occurrences of common patterns (regarding certain people, features, activities etc.). In this phase of the survey the units of analysis were words, so the intensity of the analyzed text attributes were measured by the number and percentage range of certain words ${ }^{9}$. The next phase of the survey was the computer assisted content analysis (CACA). For the research purposes the categories dictionaries were created. Those dictionaries consisted of the set of words gathered on the same semantic basis. The unit of the analysis in this phase of the research was a single paragraph and the results of that analysis were the hierarchy and key-ness of collective symbols, themes, actors and places related to Poland. In the last part of the research-as a result of factor analysis-the structure of the discourse on Poland was reduced to the strongest factors determining which different (detailed) categories have the tendency to co-occur and as such create easily distinguishable configurations.

9 The analyses were conveyed by means of software tools (Text Smart, Wordsmith Tools), which facilitate calculations, categorization, and the process of analysis, but what is even more significant, which automate the whole procedure of coding the texts. 
The frequency wordlists and percentage ranges of particular categories of computer content analysis were used to reconstruct the intensity of specific content, which was an attempt to reconstruct the mechanisms of the selection and gatekeeping processes (White, 1949; Shoemaker; Eicholz, Wrigley 2001) in the Chinese press coverage on Poland. This information - combined with keywords (together with contexts) - showed the clarity of this content, which made it possible to reveal the press agenda - the importance hierarchy of topics, heroes, values and places (McCombs, Shaw, 1972). The matrix of mutual correlations of certain key categories (and the cluster analysis based on the correlation matrix of categories), which was carried out at the last stage of the research, led to the disclosure of dominant interpretative frames (Entman, 1993), while the factor analysis proved to be an effective tool for reconstructing cardinal narratives about Poland in the Chinese press in $2015-2020^{10}$.

Our goal was to collect the most representative texts about Poland between 2015 and $2020^{11}$. In the time frame of this study, the total number of 172 articles from 63 newspapers with Poland as the main narrative was collected, with People's Daily accounting for nearly a quarter of the total amount of coverage $\mathrm{e}^{12}$. It is worth noting that in the ranking of Chinese newspapers in terms of the number of reports on Poland, the cultural newspaper Arts \& Culture News, the social research newspaper China Social Science News and the economic newspaper Economic Daily are among the top ten. The collection of the press material includes app. 160 thousand tokens (running words) in app. 7,5 thousand types (distinct words) ${ }^{13}$ in 2465 paragraphs.

The main hypotheses in our research are:

10 The list of categories (coding frame) and the full research report is available in the Press Research Centre archive.

11 The selection of texts for analysis was based on the criterion of relevance, as indicated by the algorithms implemented in the search queries of electronic archives of the Chinese press.

12 And also Xinmin Evening News (11), Guangming Daily (10), Global Times (8), China Daily (7), Cankao Xiaoxi (6), China Social Science News (6), Economic Daily (6) and China's Youth Daily (5).

13 The STTR (standardized types/token ratio) is $43,8 \%$; the mean word length (in characters) is 4,8 and the number of sentences is nearly six thousands. 
- The Chinese press pays most attention to Poland's economic and cultural development, considering Poland as a leading country in the economic development of Central and Eastern Europe.

- The media in China affirm the achievements of Sino-Polish cooperation in the fields of import and export trade (especially agricultural trade), infrastructure construction and humanistic exchanges after the implementation of the "Belt and Road" Initiative.

- The Chinese press reports on a high number of social welfare and people-friendly policies in Poland with an appreciative attitude.

- Chinese newspapers are concerned about Poland's diplomatic development with the EU and the US, affirming Poland's development after its accession to the EU, but not supporting Poland's excessive pro-Americanism.

- Chinese journalists perceive Poland as a country with profound cultural and artistic heritage.

- In terms of culture, the Chinese press is interested in Polish history (especially during WWII) and Polish literary writers, they are seen as important factors in shaping the character of the Polish people.

\section{Quantitative analysis of the Chinese press discourse on Poland: frequency lists and key-words}

The most frequent word forms in the information texts published in the dailies under study are a group of references to 'Poland' (2812 times) ${ }^{14}$, and next to 'Europe' (846), 'China' (794), 'USA' (437), 'Russia' (279), 'Germany' (184) and 'NATO' (82).

The high frequency of the word 'Chinese' (388) indicates the focus of the Chinese media on the interaction and exchanges between China and Poland, especially in terms of economic cooperation, i.e. 'Chinese...' - 'companies' (30), 'market' (25), 'consumers' (13), 'goods' (13), 'investments' (6), 'e-commerce' (6) etc. At the same time, some emphasis is placed on the development and recognition of Chinese culture in Poland, e.g. 'Chinese culture' (21) or 'Chinese calligraphy' (6) etc.

14 Including 'POLAND'S' (262), 'POLAND' (1244), 'POLISH' (1179) and 'POLES' (127). 
The Chinese media often present Poland in the context of Europe or the EU, as well as Central and Eastern Europe, partly since the implementation of the "Belt and Road' Initiative in 2016. China has paid more attention to the development of relations with the whole region of Europe (including Central and Eastern Europe), and partly because Poland's conflicts with the $\mathrm{EU}$ on issues such as refugee reception and judicial reform have attracted the attention of the Chinese media during this study period.

The Chinese media are concerned about the direction of Polish-American alliance relations and have criticized Poland for being too dependent on the US, especially in response to the increased US troop presence in Poland and the 'Huawei incident'.

Due to its historical roots, the Chinese media focus on Poland's interaction with its two neighbors, Germany and Russia (mainly in economic and political terms), as well as on media commentary on Polish-American relations in both countries.

Table 5. Frequency of word forms in particular subject areas in Chinese news reports about Poland

\begin{tabular}{|c|c|c|c|c|c|}
\hline $\begin{array}{l}\text { ECONOMY } \\
(949)\end{array}$ & $\begin{array}{l}\text { CULTURE } \\
(937)\end{array}$ & $\begin{array}{l}\text { SOCIETY } \\
(832)\end{array}$ & $\begin{array}{l}\text { MILITARY } \\
(720)\end{array}$ & $\begin{array}{l}\text { HISTORY } \\
(445)\end{array}$ & $\begin{array}{l}\text { POLITICS \& } \\
\text { LAW (975) }\end{array}$ \\
\hline $\begin{array}{l}\text { COOPERA- } \\
\text { TION (139), } \\
\text { MARKET } \\
\text { (114), PRO- } \\
\text { DUCTS (108), } \\
\text { ECONOMIC } \\
\text { (108), ECONO- } \\
\text { MY (86), } \\
\text { TRADE (82), } \\
\text { APPLES (71), } \\
\text { BELT (63), } \\
\text { AGRICUL- } \\
\text { TURAL (63), } \\
\text { DAIRY (54), } \\
\text { BUSINESS } \\
\text { (52), } \\
\text { BELT (as “Belt } \\
\text { and Road } \\
\text { Initiative") (63). }\end{array}$ & $\begin{array}{l}\text { CULTURE } \\
\text { (75), } \\
\text { CULTURAL } \\
\text { (57), } \\
\text { PENDERECKI } \\
\text { (56), THE- } \\
\text { ATER 161), } \\
\text { TOKARCZUK } \\
\text { (42), MUSIC } \\
\text { (85), CHOPIN } \\
\text { (86), CHO- } \\
\text { PIN'S (60), } \\
\text { DIRECTOR } \\
\text { (83), ART } \\
\text { 68), LITERA- } \\
\text { TURE (67), } \\
\text { UNIVERSITY } \\
\text { (63), PIANO } \\
\text { (51), MIŁOSZ } \\
\text { (25). }\end{array}$ & $\begin{array}{l}\text { LIFE (124), } \\
\text { EDUCATION } \\
\text { (97), WOMEN } \\
\text { (66), FAMILY } \\
\text { (61), RETIRE- } \\
\text { MENT (48), } \\
\text { SOCIAL (47), } \\
\text { LABOR (34), } \\
\text { CITY (115), } \\
\text { STUDENTS } \\
\text { (78), } \\
\text { UNIVER- } \\
\text { SITIES 63), } \\
\text { ABORTION } \\
\text { (25), PROTE- } \\
\text { ST(ED) (17), } \\
\text { REFORM (as } \\
\text { "social change") } \\
\text { (57). }\end{array}$ & $\begin{array}{l}\text { WAR (198), } \\
\text { MILITARY } \\
(118), \text { TROOPS } \\
(100), \\
\text { SECURITY } \\
\text { (67), NATO } \\
\text { (88), DEFENSE } \\
\text { (82), ARMY } \\
\text { (67). }\end{array}$ & $\begin{array}{l}\text { HISTORY } \\
(119), \\
\text { SOVIET (55), } \\
\text { KINGDOM } \\
(17), \\
\text { NOBLES (10), } \\
\text { JEWS (20). }\end{array}$ & $\begin{array}{l}\text { GOVERN- } \\
\text { MENT (192), } \\
\text { PRESIDENT } \\
\text { (109), PARTY } \\
\text { (88), LAW (91), } \\
\text { MINISTER } \\
\text { (82), REFORM } \\
\text { (57), JUSTICE } \\
\text { (64), } \\
\text { JUDICIAL } \\
\text { (61), } \\
\text { POLITICAL } \\
\text { (51), } \\
\text { MINISTRY } \\
\text { (51). }\end{array}$ \\
\hline
\end{tabular}

Source: own elaboration. 
One of the aims of statistical analysis of the vocabulary of a given text is to capture the characteristic features that distinguish it from other texts. This is achieved by analyzing key-words, i.e. words which appear in a given set of messages more frequently than in other texts and in the so-called comparative (reference) corpus. The authors of numerous studies carried out at Press Research Centre of the Jagiellonian University have used the technique of calculating key-words for specific sets of texts ${ }^{15}$. For this purpose, we have used, among other things, Wordsmith Tools, an IT tool for lexical analysis. It is an advanced software which determines the key word forms of the studied texts, comparing the range of occurrence of each word form from the frequency list in the studied corpus with the range of this form in the reference corpus. In this research, the reference corpus consisted of press texts about Poland published in the German, American and Russian press.

As already mentioned, key-word analysis allows us to reconstruct the unique (peculiar) features of a particular discourse. In the key-word list of the corpus covering material about Poland in the Chinese press from 20152020 , the high accumulation of words denoting the domain of culture is striking. For instance, the fact that the word "theatre" has become one of the keywords depends to a large extent on the increasingly frequent exchanges and cooperation between China and Poland in theatre in recent years, as we often read in the texts about the exchange of visits by Chinese and Polish theatre delegations and the presence of Polish directors in China. Poland is portrayed in the Chinese media as a mythical literary kingdom because of Nobel Prize winners such as Miłosz and Tokarczuk, and this aura is deeply rooted in the lives of Polish people, with news titles such as "Every breath in Poland is a taste of literature", "Free bus tickets for readers in Poland" and so on. And Marie Curie is seen as part of the Polish spirit, hard-working and dedicated. It is worth noting that the discussed list also includes a large group

15 To determine the degree of key-ness of a certain word form for a given text (or set of texts), one should consider: 1) the frequency of occurrence of the word form in the analyzed text, 2) the number of items on the frequency list of the analyzed text, 3) the frequency of the word form in a reference text (corpus), 4) the number of items on the frequency list of the reference corpus. Thus, in the list of key-words appear such items that have an unexpectedly high frequency in comparison with the reference corpus. 
of words from the category nomina propria (anthroponyms or toponyms), e.g. 'Chopin'16, 'Tokarczuk', 'Miłosz', 'Zagajewski' and many others.

At the same time, the list of key words includes a large group of words denoting the economic sphere, with particular emphasis on agriculture ${ }^{17}$. So, in the Chinese media Poland is often presented in the context of Chinese initiatives such as "One Belt, One Road", "16+1 cooperation", "China CEE cooperation". The term "development" is used in the context of "economic development of Poland", "cultural development of Poland", "agricultural development of Poland", etc. Most of the relevant articles aim at pointing out the promising prospects of Sino-Polish cooperation. Sino-Polish agricultural cooperation, especially the export of Polish agricultural products to Poland, was seen by the Chinese media as one of the achievements of " $16+1$ cooperation", with most of the news highlighting the respectable income generated by Polish farms as a result of exports to China and the promising future of Sino-Polish agricultural cooperation ${ }^{18}$.

The volume of this article does not allow for a detailed presentation of the conclusions resulting from the measurement of the frequency and key-ness of the words appearing in the Chinese press materials about Poland in 2015-2020. So let us present - in a graphic form - a synthetic map of the discourse about Poland and Poles.

In order to reconstruct the configuration of the discourse in the journalistic messages about Poland in the Chinese press, individual paragraphs (cases) were subjected to a specific analytical procedure, which takes into account both the frequency of occurrence of certain lexemes and their tendency to co-occur with others. The diagram presented below should be treated as a map that contains several different areas - clusters of categories. The size of individual areas on the map indicates how numerously a given lexeme was represented in the examined texts, whereas the distances between

${ }^{16}$ Musicians (and 'music' as a key-word) such as Chopin or Penderecki have made Poland the 'music capital' of the Chinese media, and Polish music is inevitably promoted in the news about Polish culture.

17 For instance: 'belt', 'co-operation', 'development', 'market', 'dairy, 'apples', 'agriculture', 'milk' and 'farmer'.

18 One can assume that high frequency and key-ness of such words as 'agriculture' and phrases like "One Belt, One Road" is related to the Chinese government's agenda setting. 
individual areas (but also the distances between individual elements of these areas) inform about the tendencies for their co-occurrence in the analyzed sentences. ${ }^{19}$ So the multi-stage analysis procedure led to the construction of a map illustrating the general order of the discourse on Poland in the Chinese press in 2015-2020.

The configuration of categories on the presented map makes it possible to think that the discourse about Poland in the studied dailies can be arranged according to three dimensions: 1) WELFARE (the sphere of political, economic, social (etc.) practice, especially wealth-related words including economic domains and commodities),2) WARFARE (the domain of military aspects of events, especially of war, conflict or dispute issues) and 3) ENLIGHTMENT (which refers to knowledge, art, insight, and information concerning personal and cultural relations, including certain features which reflect the valuing of skills, especially those of the arts in the aesthetics).

The broad cluster is formed by the groups of lexemes denoting the development of Poland's industry and agriculture and the prospects of China-Poland cooperation against the background of the Belt and Road Initiative. For the Polish government, the Belt and Road Initiative and the $16+1$ cooperation mechanism are seen as new opportunities for Poland's development, and it is hoped that within these frameworks, comprehensive cooperation between the two countries will be strengthened in various fields, particularly in order to expand Polish exports by taking advantage of China's economic development and market size. Poland has a large export potential to China in markets such as agriculture and livestock products. At the same time, Poland is looking forward to deepening cooperation with Chinese companies in the fields of equipment manufacturing, innovation and high technology, in order to revitalize Polish industry ${ }^{20}$.

19 Using Text Smart software, an overall picture of the discourse was constructed in the shape of a 'geographical' map of mutual relations between different categories of analysis. For the detailed methodological description see: Płaneta 2018.

20 Here are a few examples: People's Daily: "Building a mutually beneficial >two-way channel< for China-Poland trade and economic cooperation" (Wang, 2016) | "Chinese enterprises set up factories in Poland to boost local industries (Five years of the Belt and Road Initiative)" (Yu, 2018c) | Xinmin Evening News: "the Belt and Road Initiative helps Polish dairy farmers embark on the road to prosperity" (Zai,W., et al, 2017) |"Polish dairy products bullish on China's market potential Family” (Xinmin Evening News, 2016). 
Another cluster gathers the lexemes denoting the opportunities and challenges faced by Polish society in the process of globalization. With Poland's accession to the European Union and the development of globalization, people's horizons and mentality have changed. The trend towards foreign exchange and cooperation in various fields is clearly increasing. However, Polish society is also facing low fertility rates, population loss and a shortage of professional and skilled labor. The Polish government has taken a number of measures in response to this, including, for example, promoting the "renaissance" of vocational education in the education sector, opening up cross-border exchange programs and focusing on the development of international skills ${ }^{21}$.

A distinct cluster is formed by words referring to judicial conflicts between the European Union and Poland (as the representative of Central and Eastern European countries). The dispute between the Polish government and the Supreme Court not only highlights the growing conflict between Poland and the European Union over judicial reform, but also reflects the awkward situation of Central and Eastern European countries that are struggling to survive in the middle of it. At the beginning of their accession to the $\mathrm{EU}$, the CEE countries were eager to be accepted by Western Europe and to identify with its values and social model. With the successive European debt crisis, refugee crisis and Brexit crisis, as well as the rising friction between local and overall interests, the differences between the CEE countries and the $\mathrm{EU}$ on a series of issues such as domestic and foreign affairs have been increasing. The deeper reason is that the two sides tend to diverge in terms of values and social models ${ }^{22}$.

21 People's Daily: "Poland focuses on balanced forest protection and use" (Yu, 2019a) | "Controversial lowering of retirement age in Poland" (Li, 2017a) | "Poland faces "labor shortage' dilemma” (Yu, 2018)|“The UK’s “Brexit” hits the Polish labor market” (Li, 2017b) | "Love children, win the future" (Wang, 2017) | Dongfang Morning: "Ten years in Europe: How Poles see the world" (Qin\&Jin, 2015) | Global Times: "Poland's future still lies in Europe" (Liang, 2015).

22 People's Daily: “Disagreements continue, Europe's 'East-West rift' continues to deepen" (Yu, 2018d) | "Polish judicial reform exacerbates divisions with EU” (Yu, 2018b)| "EU proposes to punish Poland severely. The countries of Central and Eastern Europe hold a group against" (Ji, 2018) | Wuzhou Daily: "Poland does not accept the EU's double standards" (Tan\& Chang, 2018) | Guiyang Evening News: "Former Polish PM warns: Poland may also leave 
ENLIGHTMENT



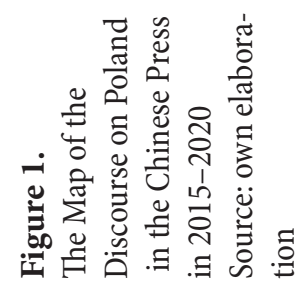


Another group of lexemes denotes problems related to the US-Russian power rivalry, with particular emphasis on the fact that Washington is more decisive (compared to Poland's Western European allies) in matters of defense and military cooperation. Poland and other Central and Eastern European countries have long been hostile to Russia and have followed the US in their foreign policy, while the "Old Europe" countries, represented by Germany, have both contradictions and common interests with Russia, and place more emphasis on European independence and internal unity. Poland is trying to promote its military modernization through military cooperation with the US, strengthen its defenses against Russia and at the same time keep other European countries in check, in order to ease the pressure on Poland within the EU on issues such as refugee sharing and judicial reform ${ }^{23}$.

Another cluster refers to the conservative and traditional values and pragmatic attitude of Poland's ruling party. The current ruling party, the Law and Justice Party, is heavily populist, with a pragmatic stance that puts national and state interests above all else, even to the point of open conflict with traditionally friendly countries; it is also heavily xenophobic, as are populist parties in other European countries; conservatism is also enshrined in the Law and Justice Party, eliminated extreme or controversial ideas from its election platform, while talking more about family policy and social welfare, which are in the interests of the majority. It strongly asserts that Poland is a religious state, which gives Catholicism an unassailable position and influence in the country ${ }^{24}$.

The burden of tragic history, a peculiar evocative discourse about the past and contemporary memory, is a humanistic reflection on the collective and individual fates of people and the memory of tragedy and death, and the most important theme in that discourse is the annihilation of Jews during WWII.

the EU" (Chen, 2017) | Jiefang Daily: "Why the Central and Eastern European countries are "unhappy after marriage"” (Wu, 2018).

23 Jilin Daily: "U.S. troop surge in Poland alerts Russia” (Wang, 2020) | Cankao Xiaoxi: "Foreign media: Poland's efforts to "befriend" the United States may make it more isolated in Europe" (2018) |"Poland to spend nearly $\$ 50$ billion to help consolidate 'NATO's Eastern Front” (Wei, 2019).

24 Global Times: "Poland's new abortion law draws protests: no surgery even for severely deformed fetuses, forcing pregnant women to leave the country” $(\mathrm{Hu}, 2020) \mid$ Cankao Xiaoxi: "Poland's Law and Justice Party: A Pragmatic Populist Party" (Han, 2016). 
For instance, the Chinese press thoroughly covered that the conservative populist Law and Justice party failed to face up to history in its eagerness to absolve itself of responsibility for the massacre of Jews ${ }^{25}$. Thus the views and discourses on the history of the Holocaust constitute a distinct group of words.

Another visible area on the presented map refers to the achievements in the fields of literature, music, film, science etc. which are the valuable heritage and pride of the Polish nation. The beauty of Poland: the multidimensional discourse on Polish success - culture and artists are the remarkable part of the discourses on Poland in Chinese newspapers. The Polish culture and art function in it not only in the European but also in the global dimension. The Chinese authors willingly present world-famous Polish artists - poets (Miłosz, Zagajewski) and prose writers (Tokarczuk), composers (Chopin, Penderecki), and film directors (Wajda). ${ }^{26}$

Chinese journalists are also interested in historical issues, especially the birth and development of Poles' "Rebellious Spirit" and struggle for their freedom and independence. The Poles have a strong sense of national dignity and manifest revolutionary leanings. So a quest for freedom that is inextricably linked to their history of several falls of the state and colonial domination, in contemporary times is more often reflected in skepticism and protest against government policies ${ }^{27}$.

25 Xinmin Evening News: "Poland's 'Exoneration Bill' Angers Israel, Talks of Jail Time for Poland's Responsibility for Holocaust" (Yu, 2018e) | Cankao Xiaoxi: "Article in the Western media: Poland intends to avoid the history of persecution of Jews" (Sun, 2017) | "Poland wants to legislate jail for saying 'Polish death camp'" (Tang, 2018)

26 People's Daily: “These Poles, whose talent belongs to the world" (Chen, 2016) |"Every breath is a breath of literature (foreign correspondent's handbook)" (Ji, 2017)|Arts \& Culture News: “Andrzej Wajda: Identity, War and Lyricism” (Li, 2019) |“Tokarczuk's 'Cloudwalking': In all the boundaries that are crossed" (Yu, 2019b) | " $>$ An understatement $<$ : Zagajewski on art and life" (Yang, 2020) | Beijing Daily: "The Polish musician named > Lao Pan $<$ (Penderecki) is gone!" (Wang, 2020) | Southern Metropolis Daily: "When the "Godfather of Polish Theater" (Lupa) met "Stetson" (Zhu, 2018).

27 Xinmin Evening News: "German 4th Panzer Division meets stiff resistance in the Polish border town of Mokra on the first day of the $>$ German-Polish War $<$ Polish cavalry brigade defeats German armor ace" (Feng, 2015) | Xinmin Evening News: "Poland's "N-Team" teases Nazi Gestapo" (Li, 2016) | Pengpai: "How Stalin and the Nazis "conspired" to destroy Poland" (Chang, 2015) | China Social Science News: "An analysis of the rise and fall of the 'Golden Age' in Poland” (He, 2020) | China Social Science News: “The absurd 'king-election' 


\section{The Main Narratives on Poland - an Attempt of Synthesis}

In order to reach more clear results on the structure of the Chinese newspapers' discourse on Poland, in the next phase of the research, statistical measurements were made using one of the multidimensional inference techniques, namely cluster analysis. As a result, the overall picture has been reduced to the most important clusters determining which different (detailed) categories have the tendency to co-occur and that is why they create easily distinguishable configurations in the examined texts that refer to characters, problems, values and places, which makes it possible to call such separate configurations the main narratives about Poland in the Chinese press in 2015-2020.

The most expressive narrative about Poland is constituted by the categories which, in their combined configuration (C.II) denote the fact that POLAND RIDES ON THE “BELT AND ROAD” BANDWAGON [4165]. Thus, the economic cooperation between China and Poland in the field of infrastructure, agriculture, and new industries is exposed in the analyzed materials, as well as the most promising industry of economic and trade cooperation between China and Poland. Exceptionally much has been written about Polish agricultural products exploring Chinese market and the fact that Chinese e-commerce is favored by Polish people (Tang, 2016; Zai, Han \& Shuai, 2017; Zhang, Chen, 2020; Yu, 2020; Wang, 2021).

Poland is the gateway to Europe for China's Belt and Road Initiative, a key transportation hub in Europe, and a "leader" of CEE countries. China attaches particular importance to cooperation with Poland in various fields looking forward to "building a mutually beneficial "two-way channel" for China-Poland trade and economic cooperation". The desires of both sides in terms of economic cooperation are clear. Poland wants to further expand its exports to the Chinese market and attract investment, while China intends to increase its investments in Poland, including infrastructure, new energy, machinery manufacturing, biomedicine, etc. (Wang, Wang, 2016).

and the 'veto' in modern Poland" (Guo, 2019) | Social Science Journal: "Poland as a mirror and metaphor" (Xiong, 2020). 
In terms of the achievements of Sino-Polish economic cooperation, first and foremost, win-win results of the cooperation between the two sides were highlighted. For example, the presence of Chinese companies in Poland has had a significant impact on local employment and economic development, therefore, such investments are in line with the countries' willingness to revitalize their economies and also allow Chinese companies to better integrate into the international market and gain access to advanced research, production technologies and management experience, Chinese companies (LiuGong Rista) help revive Poland's "Steel City" (Stalowa Wola), "Shanghai Fair finds buyers for Polish amber" "Chinese companies (Hongbo Lighting) set up factories in Poland to boost local industries" etc. (Yu, 2018c; Wang, 2016).

Secondly, the media highlighted the significant benefits and potential that Poland had achieved in its agricultural and logistics cooperation with China, with the terms "apples", “dairy products", "fruit farmers", "China-Europe trains" and "Minister of Agriculture" often dominating the coverage. There are even several feature stories on related topics, such as "The Belt and Road Initiative helps Polish dairy farmers embark on the road to prosperity", "Polish dairymen look to make their mark in the Chinese market", "Chinese e-commerce companies gain a large number of fans in Poland" (Zai, Han, Shuai, 2017; Wang, 2021).

In the analyzed newspapers C.II thread co-exists with another - C.I - the area of the discourse formed by categories denoting POLAND AS THE LEADER OF THE REGION AND WARSAW'S STRUGGLE FOR STATUS AND VOICE IN EUROPE [3991]. As for the detailed themes in this narrative, they are, firstly, the conflicts between Poland and the EU over judicial reform, media control, refugee policy, secondly, a narrative about the violation of the constitution and political dominance over the judiciary and-finally-the CEE countries and Western European tendency to diverge in terms of values and social models (Wu, 2018; Yu, 2018c).

The Central and Eastern European countries, represented by Poland and Hungary, are increasingly at odds with Western European countries in the fields of migration, justice, media and religion. Poland and the European Union are in constant disagreement over judicial reform, showing a different attitude than when it first joined the EU in 2004, which is inseparable from the rapid development of democracy and economy in CEE countries (Yu, 2018d). 
In addition, along with the slowdown of European integration, Western European countries advocate the construction of "multi-speed Europe", a development concept explicitly opposed by the Polish government. Fearing that they will become "second-class citizens" within the EU, the CEE countries have openly confronted the EU on a number of contradictory issues, which, according to public opinion, may trigger a "domino effect" and cause other EU member states to follow suit. "While fighting for their own interests, they will be more active in expressing their demands to the EU" (Yu, 2018b; Yu, 2018d).

However, Poland will not follow in the footsteps of the UK, as it is the biggest beneficiary of EU funds and one of the considerations for joining the EU was to deal with the Russian threat, and while these factors still exist, Poland cannot afford to leave the EU and will maintain a "struggle without breaking relations" with the EU (Ji, 2018; Yu, 2018b).

When Central and Eastern European countries such as Poland and Hungary joined the EU, they were "eager to be accepted by Western Europe and to identify with its values and models". Since the outbreak of the debt and refugee crises in Europe, the CEE countries, represented by Poland and Hungary, have become increasingly divided with Western European countries in issues such as migration and justice. The reason for this phenomenon according to the Chinese media is that "New Europe" (incl. Poland) and "Old Europe" are varying in stages of development, problems encountered and aspirations for democracy. The dispute between the two is in fact a dispute over development models and paths, which is a conundrum for EU integration ( $\mathrm{Wu}, 2018 ; \mathrm{Yu}, 2018 \mathrm{~d}$ ).

Another narrative (C.III) identified in the analyzed press releases concerns THE AXIOLOGICAL AND IDEOLOGICAL DILEMMAS OF CONTEMPORARY POLISH DEMOCRACY [3080]. Chinese journalists repeatedly expose opinions unfavorable to Warsaw, according to which the party in power in Poland ("Law and Justice") pursues policies that are completely contrary to EU standards. Moreover, "majority rule"-despite its democratic mandate-poses a threat to minority rights. The Chinese authors see the "Law and Justice" as a pragmatic party with populist tendencies, but at the same time they criticize the U.S. interference in Polish democracy, such as the U.S. government intervention in Polish elections, which allegedly weakened the democratic electoral process in Poland (Han, 2016; Zhang \& Chen, 2020, Yu, 2018d). 
C.I. POLAND AS THE LEADER OF THE REGION AND WARSAW'S STRUGGLE FOR STATUS AND VOICE IN EUROPE

Conflicts between Poland and EU over judicial reform, media control, refugee policy and a narrative about the violation of the constitution and political dominance over the judiciary. CEE countries and Western European tend to diverge in terms of values and social models

C.II. POLAND RIDES ON THE "BELT AND ROAD" BANDWAGON Economic cooperation between China and Poland in the field of infrastructure, agriculture, and new industries. The most promising industry of economic and trade cooperation between China and Poland: Polish agricultural products explore Chinese market. Chinese e-commerce is favored by Polish people

C.III. THE AXIOLOGICAL AND IDEOLOGICAL DILEMMAS OF CONTEMPORARY POUSH DEMOCRACY Opinions unfavorable to Warsaw, according to which the party in power in Poland ("Law and Justice") pursues policies that are completely contrary to EU standards; "majority rule" - despite its

democratic mandate-poses a threat to minority rights; "Law and Justice" as a pragmatic party with populist tendencies; U.S. interference in Polish democracy

C.IV. THE VIEWS AND DISCOURSES ON THE GLOBAL EXPERIENCE OF HOLOCAUST The emphasis of the conflict between the Polish government and Israel on Polish legislation

C.V. THE TREASURES OF POLAND

The beauty of the cities and natural environment. Poland is blessed with natural scenery and historical and cultural resources

CVI. THE CULTURAL LEGACY AND GLORY OF POLAND The multidimensional discourse on Poland's achievements culture, art, education - in the past and present

C.VII. THE HUMANISTIC CARE AND THE POLISH SOCIETY The Women's rights, children, people with disabilities are given special attention (e.g. 500+ policy, NGO WOŚP, noble packages)

C.VIII. ON DEFENSE ISSUES AND MILITARY RIVALRY AND CO-OOPERATION Poland - Russia endangers Poland's territorial security, and the US is tougher on Russia than its Western European

C.IX. THE REMEMBRANCE OF WWII AND TOTALITARIANISM The discourse on war reparations and other contentious issues between Poland, Nazi Germany and the Soviet Union. Poland's struggle for independent democracy is appreciated, while the shirking of historical responsibility is criticized

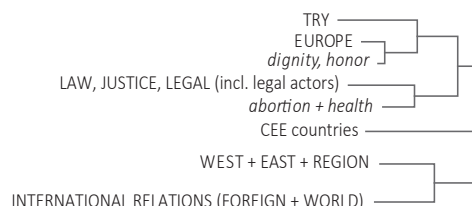

CHINA (incl. Chinese names)

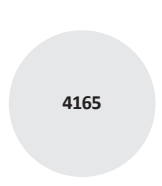

ASIA + Łó

TECHNOLOGY + COMMUNICATION + CONSTRUCTION

globalization



modernity, innovation + skills actors



democracy

pendence, sovereignity

welfare + elite + oligarchy consens

fight, rivalry

fail + order, stabilization $\neg$

crime, corruption

POLISH POLITICIANS NAMES + MALE

success, win + PERSIST + GOAL -

patriotism + FEEL

communism, socialism, left-wing
2120

WORLD + peace
AUSCHWIT

HISTORY + heritage, legacy, tradition

nationalism + exploitation, colonialism, imperialism RELIGION + SPIRTUAL, TRANSCEDENCY

hatred + disgrace, shame poverty
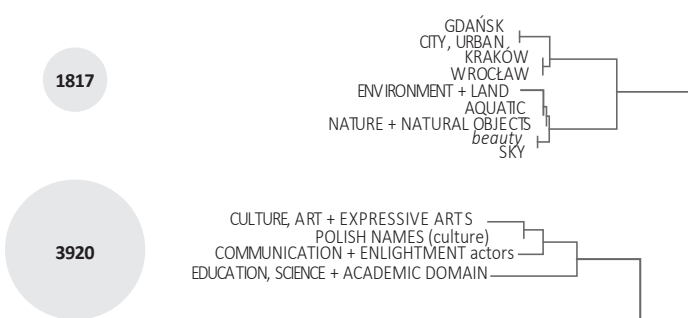

CULTURE, ART + EXPRESSIVE ARTS

POLISH NAMES (culture)
COMMUNICATION + ENLIGHTMENT

COMMUNICATION + ENLIGHTMENT aCt
EDUCATION, SCIENCE + ACADEMIC DOMAIN

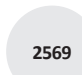

2569

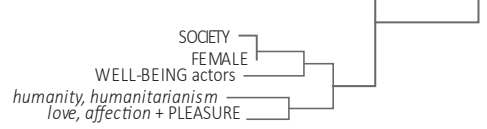

love, affection + PLEASURE
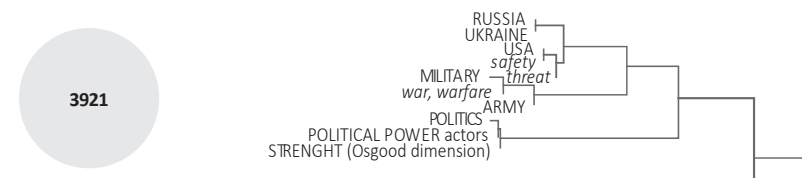

POLITICS STRENGHT (Osgood dimension)
479 POLITICAL POWER AUTHORITHATIAN aCtOrS SERMANY

$$
\begin{aligned}
& \text { NAZIS } \\
& \text { nazism, fascism }
\end{aligned}
$$



Figure 2. The Main Narratives on Poland in the light of the factor analysis results Source: own elaboration 
THE VIEWS AND DISCOURSES ON THE GLOBAL EXPERIENCE OF HOLOCAUST (C.IV) [2120] is another visible "media story" about Poland in the Chinese press. It should be noted that the specific plot of this media story is the emphasis of the conflict between the Polish government and Israel on Polish legislation (Sun, 2017).

The separate narrative about Poland in Chinese newspapers is related to the tragic history of the 20th century and its commemoration (C.IX. THE REMEMBRANCE OF WWII AND TOTALITARNISM [479]). In this narrative, the reader will find many references to the discourse on war reparations and other contentious issues between Poland, Nazi Germany and the Soviet Union. Poland's struggle for independent democracy is appreciated, while the shirking of historical responsibility is criticized (Chang, 2015).

The beauty of the cities and natural environment is the foundation for another narrative (C.V.), which can be described as THE TREASURES OF POLAND [1817]. According to this media coverage Poland is blessed with natural scenery and historical and cultural resources (Mao, 2019).

Chinese journalists are also strongly interested in exposing the multidimensional discourse on Poland's achievements in culture, art, education (Ji, 2017). It should be added here that the number of paragraphs [3920] referring to C.VI. thread (THE CULTURAL LEGACY AND GLORY OF POLAND) is relatively high.

In discussions about culture, Poland is a country with a rich history and cultural heritage. Not only are such "greats of world culture and science" as Copernicus, Chopin and Madame Curie often mentioned in the Chinese media, but award-winning Polish literary giants such as Tokarczuk, Miłosz, Schulz and Zagajewski are also coming to the forefront of Chinese readers' minds. It is worth noting that Polish culture, especially Polish literature has always been closely related to the history and destiny of the nation. Poles have suffered from foreign oppression, experienced brutal World War I, World War II and the Cold War, which gave birth to the literary masterpieces that directly or indirectly express the spirit of resistance and made Polish literature famous for generations. Poets are the "prophets and visionaries" of the nation, and literature is "service, an important task and a mission", so to speak. This is the core of Polish literature's tradition. Tokarczuk is the inheritor of this literary tradition (Ji, 2017). 
The Polish film school, theater, painting, music and poster art are often described in great detail by Chinese experts in the field, who are often "overwhelmed by the imagination and richness of content" in Polish arts. In addition to the historically famous artists such as Chopin and Matejko, Polish modern artists are also noticed by the Chinese media, including masters such as Wajda, Penderecki, Lupa, Polański, most of whom paid visits to China. With the increasing cultural exchange between China and Poland, some young and emerging artists in the field of Polish theater and film also attract Chinese readers (Wang, 2018).

In the Chinese media, Poland's painful history has convinced Poles that the country's strength lies in education. Poland has a rich humanistic heritage, "ranks in the top 10 of the world's top higher education countries" and "Polish universities have produced many famous scholars and scientists". In addition, "Polish higher education is a combination of European tradition, high quality and cost-efficiency", which attracts more and more Chinese students (Li, 2017).

Another distinct narrative (C.VII.) in contemporary media in China concerns THE HUMANISTIC CARE AND THE POLISH SOCIETY [2569], especially women's rights as well as the social and economic situation of children, people with disabilities who are given special attention (e.g. 500+ policy, NGO: The Great Orchestra of Christmas Charity, Noble Packages, etc.) (Li, 2016).

An extensive and separate narrative about Poland in Chinese newspapers - C.VIII. ON DEFENSE ISSUES AND MILITARY COOPERATION [3921] - concerns Polish-Russian relations, especially the fact that Russia endangers Poland's territorial security, and the US is tougher on Russia than its Western European allies (Wang, 2020).

\section{Closing remarks}

For most Chinese, Poland is both a familiar and unfamiliar country. Poland is well known for its wartime and social transition history, and those Poles who changed the world-Mikołaj Kopernik, Fryderyk Chopin and Maria Skłodowska-Curie. However, less is known about modern post-transformation Poland, as the CEE region had not been a major center of attention 
in China until the Belt and Road Initiative (2012) was launched. There are also many references to history, geography, and politics for all these reasons.

As in the case of history and politics, Poland is often depicted as "foot wraps of Europe", "a country reborn from the ashes" and "a model of economic transition", "pioneer of democracy" and also as the "leader in CEE". The first two of these names depict Poland, which has been invaded and ravaged several times, respectively showing its weakness and its indomitable national spirit. The third and fourth refer to Poland's role as a pioneer in the economic transformation in Central and Eastern Europe, where it has made a series of innovative initiatives with remarkable results and become a leader in the region.

Poland has shown a certain level of "pragmatism"28 and "populism" in both domestic and foreign affairs and lacks long-term sustainable planning. Internally, Poland is constantly enacting new policies in order to appeal to its voters and consolidate its rule.

The political nicknames are related to the Polish-American military alliance, such as "America's bridgehead against Russia", "exemplary students in NATO", expressing its concern for territorial security and dependence on the military power of other countries, and therefore these designations are derogatory (Wei, 2019).

Metaphorical expressions for Poland also include such phrases as the "factory of Europe"29, "a country full of literature", "an oasis of nature". The first concept shows that Poland is a major European manufacturing country and a leader in Europe in a number of areas such as furniture, metalworking, and household appliance production. The second and third respectively indicate that Poland is a great literary country with a rich humanistic heritage, as well as a good natural environment with abundant natural tourism resources (Ji, 2017; Yu, 2019).

28 The results of MOTIVATION-RELATED categories in CACA procedures show that Poland is presented in the Chinese media as a practice-oriented country, willing to experiment and change according to needs, but lacking long-term goals to stick to. As far as results are concerned, the majority of practices are effective.

${ }^{29}$ China Daily: Poland may have become a "European factory" (2018) Retrieved from:http://world.chinadaily.com.cn/2018-01/23/content_35566669.htm. 
The configuration of the values and anti-values reflected in the news shows that the following values appear most frequently: prosperity, dignity, glory, love $e^{30}$, beauty, globalization, resistance ${ }^{31}$ and threats ${ }^{32}$, and the overall image of Poland in the Chinese media is - once again- positive $^{33}$. Prosperity and globalization are reflected in the rapid growth of the economy ${ }^{34}$. Thus, Poland is perceived as "Europe's Crossroads" or "Europe's main transport corridors", which emphasize the fact that Poland is located in the geographical center of Europe and has unique geographical advantages as "The Gateway to Europe".

\section{LIC. CAO YANG}

Instytut Dziennikarstwa, Mediów i Komunikacji Społecznej

Uniwersytet Jagielloński w Krakowie

ul. prof. Stanisława Łojasiewicza 4, 30-384 Kraków

cy45978159@gmail.com

\section{DR PAWEŁ PŁANETA}

Ośrodek Badań Prasoznawczych

Instytut Dziennikarstwa, Mediów i Komunikacji Społecznej

Uniwersytet Jagielloński w Krakowie

ul. prof. Stanisława Łojasiewicza 4, 30-384 Kraków

pawel.planeta@uj.edu.pl

30 The values of dignity, glory and love are mainly reflected in the cultural, historical and social dimensions.

31 Resistance, which is rooted in the Polish national spirit of rebellion, is reflected in literature, historical themes and, to a lesser extent, in the coverage of social themes. However, domestic protests against women's rights and the Church have not been the focus of coverage, but rather the resistance of the Polish government has been more prominent in foreign relations.

32 The anti-value of threat is often expressed in reports on Polish-American cooperation, especially when it comes to military cooperation, often with the help of quotes from Western European media such as Russia or Germany.

33 On the other hand, the range of COGNITIVE ORIENTATION categories of content analysis proves that Chinese media mainly present news events, reporting them objectively, focusing on details and integrity, comparing them with similar events or quoting speculation from other media, and rarely making positive judgments or expressing subjective opinions.

34 But also in the development of culture and the arts. 


\section{Bibliography}

Berelson, B. (1952). Content analysis in communication research. New York: Free Press.

Deng, T. (2018), Zouguo Fanrong Xingsheng Guaidianhou Zaixunlu - Zhongguo Baoye 40 Nian Huimou 走过繁荣兴盛拐点后再寻路——中国报业 40 年回眸 [China’s newspaper industry finds its way after a prosperous inflection point - A look back at 40 years of the Chinese newspaper industry], Culture Industry, 112(15), 1-6.

Góralczyk, B. (2017). Geostrategia Xi Jinpinga - Chiny ruszaja w świat. Rocznik Strategiczny, 22.

Góralczyk, B. (2018). Wielki renesans. Chińska transformacje i jej konsekwencje. Warszawa: Wydawnictwo Akademickie Dialog.

Guo, K. (2010). Newspaper: An Industry in Transition. In: J.F. Scotton, W.A. Hachten (eds.), New Media for a New China (41-57). Malaysia: Wiley - BlackWell.

Hu, S.Y. (2009). Zhongguo Baoye Fazhan De Xianzhuang Yu Qushi 中国报业发展的现 状与趋势 [Current situation and trends in the development of China's newspaper industry], News Outpost, 2, 14-18.

Kelly, E., Stone, P. (1975). Computer Recognition of English Word Senses. North-Holland Linguistic Series.

Krippendorf, K. (1980). Content Analysis: An Introduction to its Methodology. Beverly Hills, CA.: Sage Publications.

Kupś, H., Szatkowski, M., Dahl, M. (red.). (2021). 70 lat Chińskiej Republiki Ludowej w ujęciu interdyscyplinarnym. Warszawa: Wydawnictwo Akademickie Dialog.

Lula, P. (2005). Text mining jako narzędzie pozyskiwania danych $z$ dokumentów tekstowych. Retrieved from: https://media.statsoft.pl/_old_dnn/ downloads/text_mining_jako_narzedzie_pozyskiwania.pdf.

Lv, S.B. (2010). Zhongguo Baoye Zhuanxing Fazhan De Sida Zhanlue Zouxiang 中国报 业转型发展的四大战略走向 [Four strategic directions for the transformation and development of China's newspaper industry], China Newspaper Industry, 1, 19-24. DOI:10.13854/j.cnki.cni.2010.03.010.

Marszałek-Kawa, J. (ed.). (2014). Globalna potega Chin. Czynniki i perspektywy. Toruń: Wydawnictwo Adam Marszałek.

Marszałek-Kawa, J., Dmochowski, T. (eds.). (2018). Rozważania o kierunkach współczesnej polityki Chin. Toruń, Wydawnictwo Adam Marszałek.

McCombs, M., Shaw, D. (1972). The Agenda Setting Function of the Mass Media. Public Opinion Quarterly, 36, 176-187.

Nan, C.S. (2011). Zhongguo Dalu Baozhi Zhuanxing - Lv Shangbin 《Zhongguo Dalu Baozhi Zhuanxing》Pingzhi 中国大陆报纸转型一吕尚涁《中国大陆报纸转 型》评鸫 [Transformation of Newspapers in Mainland China - Review of “Transformation of Newspapers in Mainland China" by Shangbin Lu], Publishing Research, 1, 63-64.

Osgood, C.E., et al. (1975). Cross-Cultural Universals of Affective Meaning, Urbana.

Pisarek, W. (1983). Analiza zawartości prasy. OBP RSW „Prasa - Książka - Ruch”.

Pisarek, W. (2007). O mediach i języku. Kraków: Universitas.

Płaneta, P. (2018). Komputerowa analiza tekstu w dyskursach medialnych. In: A. Szymańska, M. Lisowska-Magdziarz, A. Hess (eds.), Metody badań medioznawczych $i$ ich 
zastosowania (65-88). Kraków: Instytut Dziennikarstwa, Mediów i Komunikacji Społecznej.

Shoemaker, P., Reese, S. (1996). Mediating the Message: Theories of Influence on Mass Media Content. New York: White Plains, Longman.

State Press and Publication Administration. (2020, Sep.). 2019 Nian Quanguo Xinwen Chubanye Jiben Qingkuang 2019 年全国新闻出版业基本情况 [Basic information on the national press and publishing industry in 2019]. Retrieved from: http://www. nppa.gov.cn/nppa/upload/files/2020/11/a0fbd38dab39dd1f.pdf.

Stone, P.J., et al. (1966). The General Inquirer: A Computer Approach to Content Analysis. The MIT Press.

Yan, Z.H. (2014, May 10). Dangbao Toutiao Yaosu Yanjiu _-Yi Xinhua Ribao (1978-2003Nian) Weili 党报头版要素研究——以新华日报（1978-2003 年) 为例. Retrieved from: https://kreader.cnki.net/Kreader/CatalogViewPage.aspx ?dbCode $=c d m d \&$ filename $=1014418685$. nh $\&$ tablename $=$ CDFDLAST 2015\&compose $=\&$ first $=1$ \&uid $=$.

\section{Selected press materials}

Chang, M.S. (2015, Aug. 4), Sidaxin Yu Nacui Ruhe “Hemou” Cuihui Bolan 斯大林与纳 粹如何“合谋”摧毁波兰 [How Stalin and the Nazis „, conspired” to destroy Poland], Pengpai. Retrieved from: https://cul.qq.com/a/20150804/018078.htm.

Che, B. (2016, Jun. 19), Zhexie Bolanren, Tamen De Caihua Shuyu Shejie 这些波兰人,他 们的才华属于世界 [These Poles, whose talent belongs to the world], People's Daily. Retrieved from: http://world.people.com.cn/n1/2016/0619/c1002-28456568.html.

Chen, Q.Y.(2018, Jan. 18), Bolan Yeyao Tuoou? Zhuanjia: Kenengxing Buda 波兰也要脱 欧? 专家: 可能性不大 [ Poland also want to leave the European Union? Experts: it's unlikely], People's Daily. Retrieved from: https://baijiahao.baidu.com/s?id=1589 $891300370243561 \& w f r=$ spider $\&$ for $=$ pc.

Feng, R. (2019, Sept. 9), Bolan Weihe Yu Meiguo Yibuyiqu 波兰为何与美国亦步亦趋 [Why Poland is following in the footsteps of the US], Hunan Daily. Retrieved from: https://hnrb.voc.com.cn/hnrb_epaper/html/2019-09/09/content_1410766.htm.

Guo, C.L. (2019, Dec. 30), Jindai Bolan Huangtang De “Xuanwangzhi”Yu "Fou Juequan” 近代波兰荒唐的“选王制”与“否决权” [The absurd „king-election”and the ,veto” in modern Poland], China Social Science News. Retrieved from: http://www.cass.cn/ xueshuchengguo/xscg_lsyjy/201912/t20191230_5066569.shtml.

Han, M. (2015, May 27), Bolan Zongtong Xuanju Yuanhe Chu Heima 波兰总统选举 缘何出黑马 [Why there's dark horses in Poland's presidential election?], Hainan Daily. Retrieved from: http://hnrb.hinews.cn/html/2015-05/27/content_11_7.htm.

Han, M. (2016, Dec. 16), Bolan Falvyugongzheng Dang: Shiyongzhuyi De Mincui Zhengdang 波兰法律与公正党: 实用主义的民粹政党 [Poland's Law and Justice Party: A Pragmatic Populist Party], Cankao Xiaoxi. Retrieved from: http://www. cankaoxiaoxi.com/world/20161216/1525463.shtml.

Han, S. (2021, Feb. 16), Zhongguo-Zhongdongou WenhuaJiaoliu Zoushen Zoushi 中国一中东欧文化交流走深走实 [Cultural exchange between China and CEE goes deeper with mutual appreciation], People's Daily. Retrieved from: http://paper. people.com.cn/rmrb/html/2021-02/16/nw.D110000renmrb_20210216_1-03.htm. 
He, F. (2020, Nov. 2), Qianxi Bolan “Huangjinshidai” De Xingshuai 浅析波兰“黄金时 代”的兴衰 [An analysis of the rise and fall of the “Golden Age" in Poland], China Social Science News. Retrieved from: https://baijiahao.baidu.com/s?id=1682234399 $687728081 \& w f r=$ spider\&for $=p c$.

Hu, J.Y. (2020, Dec. 14), Bolan Xin Duotai Fagui Yin Kangyi 波兰新邽胎法规引抗议 [Poland's new abortion law draws protests], Sina. Retrieved from: https://baijiahao. baidu.com/s?id=1686044308554095878\&wfr $=$ spider \&for $=p c$.

Ji, P.J. (2017, Dec. 27), Meiyici Huxi Doushi Wenxue De Qixi 每一次呼吸都是文学的气 息 [Every breath is full of literature (foreign correspondent's handbook)], People's Daily. Retrieved from: http://www.cssn.cn/wh/wh_wtsy/201712/t20171227_3795641. shtml.

Ji, P.J. (2018, Jan. 9), Oumeng Tiyi Yancheng Bolan Zhongdongouguojia Baotuan Fandui 欧盟提议严惩波兰中东欧国家抱团反对 [EU proposes tougher penalties for Poland, CEE countries unite against it], People's Daily. Retrieved from: http://world. people.com.cn/n1/2018/0109/c1002-29752982.html.

Li, X.H. (2016, Feb. 19), Bolan “N Xiaozu” Xinong Nacui Gaishitaibao 波兰“N小组”戏 弄纳粹盖世太保 [Poland’s „N-Team” teases Nazi Gestapo], Xinmin Evening News. Retrieved from: http://xmwb.xinmin.cn/html/2016-02/19/content_27_2.htm.

Li, X.Y. (2019, Nov. 6), Anjieyi Wayida: Shenfen Zhanzheng Yu Shuqing 安杰伊.瓦伊 达：身份、战争与抒情 [Andrzej Wajda: Identity, War and Lyricism], Literature and Art News, Retrieved from: http://www.chinawriter.com.cn/n1/2019/1106/ c419388-31440027.html.

Li, Z.W. (2016, Dec. 26), “Gaoshang Baoguo” Ji Wenqing “高尚包裹”寄温情 [A “noble parcel” of warmth], People's Daily. Retrieved from: http://world.people.com.cn/ n1/2016/1224/c1002-28973671.html.

Li, Z.W. (2017, Apr. 5), Yingguo Touou Chongji Bolan Laowu Shichang 英国“脱欧”冲 击波兰劳务市场 [Brexit hits Polish labor market], People's Daily. Retrieved from: http://www.xinhuanet.com/world/2017-04/05/c_129524698.htm.

Liang, X.J. (2015, Nov. 4), Bolan De Weilai Rengzai Ouzhou 波兰的未来仍在欧洲 [Poland's future still lies in Europe], Arts \& Culture News. Retrieved from: http://world. people.com.cn/n/2015/1104/c157278-27774774.html.

Mao, L. (2019, Dec. 16) You Bolan Wuda Jingxi Dengzhe Ni 游波兰，五大“惊喜”等着 你 [Five “surprises" await you when you visit Poland], People's Daily. Retrieved from: https://baijiahao.baidu.com/s?id=1653025562167598243\&wfr=spider\&for=pc.

Qin, H.\& Jin, Y. (2015. Aug. 15), Ruou Shinian: Bolanren Zenyang Kan Shijie 入欧十 年: 波兰人怎样看世界 [Ten years in Europe: How Poles see the world], Oriental Morning Post. Retrieved from: https://cul.qq.com/a/20150811/024058.htm.

Sun, X. (2017, Mar. 29), Ximei Wenzhang: Bolan Youyi Huibi Pohai Youtairen Lishi 西 媒文章: 波兰有意回避迫害犹太人历史 [Article in the Western media: Poland intends to avoid the history of persecution of Jews], Cankao Xiaoxi. Retrieved from: http://column.cankaoxiaoxi.com/2017/0329/1824713.shtml.

Tan, Z.P. (2016, Jan. 29), Bolan Nanzihan Guanche Fangeluxian “波兰男子汉”贯彻“防 俄路线” [The "Polish man” follows the "anti-Russian line”?], Xinmin Evening Daily. Retrieved from: http://xmwb.xinmin.cn/lab/xmwb/html/2016-01/29/content_26_1. htm. 
Tang, L.B. (2018, Feb. 8) Bolan Banbu “Datusha” Falv Yin Zhengyi 波兰颁布“大屠杀” 法律引争议 [Poland's controversial law on 'Holocaust'], Cankao Xiaoxi. Retrieved from: http://www.cankaoxiaoxi.com/world/20180208/2255225.shtml.

Wang, B.K., \&Wang, Z.Y. (2016, Jun. 20), Dazao Zhongbo Jingmao Huligongying "Shuangxiang Tongdao” 打造中波经贸互利共赢“双向通道” [Building a mutually beneficial „two-way channel” for China-Poland trade and economic cooperation], Economic Daily. Retrieved from: http://paper.ce.cn/jjrb/html/2016-06/20/content_303966.htm.

Wang, H.Z. (2020, Aug. 25), Mei Zengbing Bolan Yin Eluosi Jingti 美增兵波兰引俄罗 斯警惕 [U.S. troop's surge in Poland alerts Russia], China National Defense News. Retrieved from: https://mil.gmw.cn/2020-08/25/content_34116881.htm.

Wang, Z.Q. (2017, Feb. 8), Ai Haizi Ying Weilai 爱孩子 赢未来 [Love for children can win the future], People's Daily. Retrieved from: https://www.sohu. com/a/125706350_114731.

Wei, J. (2019, Feb. 12), Jingwaimeiti: Bolan Nuli “Bajie” Meiguo Huo Ling Qi Zai Ouzhou Gengxian Guli 境外媒体: 波兰努力“巴结”美国 或令其在欧洲更显孤立 [Foreign media: Poland's efforts to „befriend” the United States may make it more isolated in Europe], Cankao Xiaoxi. Retrieved from: http://www.cankaoxiaoxi.com/ world/20190212/2371378.shtml.

Wu, X.Y. (2020, Mar. 30), Bolan Yinyue Dashi Laopan Zoule 波兰音乐大师老潘走 了 [Polish music master "Laopan" (Penderecki) has gone], Xinmin Evening News. Retrieved from: http://paper.xinmin.cn/html/xmwb/2020-03-30/11/63634.html.

Wu, Z.L. (2018, Sept. 10) „Hunhoubuxing” De Zhongdongou Guojia Weihe Ganga “婚后 不幸”的中东欧国家为何筳尤 [Why the Central and Eastern European countries are unhappy after "marriage with EU”], Jiefang Daily. Retrieved from: http://www. cssn.cn/sjs/sjs_rdjj/201809/t20180910_4557083.shtml.

Xiong Y.Z. (2020, Jul. 31) Zuowei Jingjian Yu Yinyu De Bolan 作为镜鉴与隐喻的波 兰 [Poland as a mirror and metaphor], China Social Science News. Retrieved from: https://xuewen.cnki.net/CCND-SHKX202007300080.html.

Xinmin Evening News. (2016, May 11), Bolan Ruzhipin Kanhao Zhongguoshichang Qianli 波兰乳制品看好中国市场潜力 [Polish dairy products bullish on China's market], Xinmin Evening News. Retrieved from: http://xmwb.xinmin.cn/home/ html/2016-05/11/content_13_4.htm.

Yang, J. (2020, Feb. 10), “Qingmiaodanxie”: Zhajiayefusiji Lun Yishu Yu Rensheng “轻 描淡写”: 扎加耶夫斯基论艺术与人生 [“An understatement”: Zagajewski on art and life], Arts \& Culture News. Retrieved from: http://www.chinawriter.com.cn/ n1/2020/0210/c404092-31578888.html.

Yu, S. (2020, Feb.10), Ouerjia Tuokaerqiuke <Yunyou>: Zai Bei Kuayue De Suoyou Jiexian Zhong 奥尔加 - 托卡尔丘克《云游》: 在被跨越的所有界限中 [Olga Tokarczuk's “Cloudwalking”: In all the boundaries that are crossed], Arts \& Culture News. Retrieved from: https://new.qq.com/rain/a/20200217A06HE600.

Yu, Y. (2018a, Apr. 17), Bolan Mianlin Yonggonghuang Jiongjing 波兰面临“用工荒”謇 境 [Poland faces 'labor shortage' dilemma], People's Daily. Retrieved from: http:// world.people.com.cn/n1/2018/0417/c1002-29930029.html. 
Yu, Y. (2018b, Aug. 6) Bolan Sifa Gaige Jiaju Yu Oumeng Fenqi 波兰司法改革加剧 与欧盟分歧 [Polish judicial reform exacerbates divsions with EU], People's Daily. Retrieved from: http://world.people.com.cn/n1/2018/0806/c1002-30209999.html.

Yu, Y. (2018c, Aug. 27), Zhongqi Zai Bolan Shechang Daidong Dangdi Chanye Fazhan (Gongshang Gongjian Gongxiang.Yidaiyilu Changyi Wuzhounian) 中企在波兰 设厂带动当地产业发展（共商 共建 共享 - 一带一路倡议五周年） [Chinese enterprises set up factories in Poland to boost local industries (Five years' implementation of the Belt and Road Initiative)], People's Daily. Retrieved from: http:// www.cssn.cn/jjx/jjx_gdxw/201808/t20180827_4549761.shtml.

Yu, Y. (2018d, Sept. 19), Juyu Buduan Ouzhou“Dongxi Liehen”Chixu Jiashen 龂龉不 断, 欧洲“东西裂痕”持续加深 [Disagreements continue, Europe’s „East-West rift” continues to deepen], People's Daily. Retrieved from: http://world.people.com.cn/ n1/2018/0919/c1002-30301536.html.

Yu, Y. (2019, Apr. 10), Bolan Zhuzhong Pingheng Senlin Baohu He Liyong 波兰注重平 衡森林保护和利用 [Poland focuses on balanced forest protection and use], People's Daily. Retrieved from: http://travel.people.com.cn/n1/2019/0410/c41570-31021519. html.

Yu, Y. (2020, Sept. 20), Zhongguo Shichang Chengwei Zhongdongou Nongchanpin Chukou Xinzengzhangdian中国市场成为中东欧农产品出口新增长点 [Chinese market becomes new growth point for CEE agricultural exports], People's Daily. Retrieved from: http://paper.people.com.cn/rmrb/html/2020-09/20/ nw.D110000renmrb_20200920_1-03.htm.

Zai,W., et al. (2017, May 9), “Yidaiyilu” Zhu Bolan Nainong Zoushang Zhifulu “一带一 路”助波兰奶农走上致富路 [The Belt and Road Initiative helps Polish dairy farmers embark on the road to prosperity], Xinmin Evening News. Retrieved from: http:// www.xinhuanet.com/world/2017-05/09/c_129596905.htm.

Zhang Z., \& Chen X. (2020a, Jul. 13) Tongji Jieguo Xianshi Bolan Zongtong Duda Shengxuan Lianren 统计结果显示波兰总统杜达胜选连任 [Polish President Duda wins re-election, according to statistics], Xinhua Daily. Retrieved from: http://www.xinhuanet.com/world/2020-07/13/c_1126232404.htm.

Zhang Z., \& Chen X. (2020b, Nov. 11), Bolan Ruzhipinshang Qidai Jiezhu Zhongguo Shichang Dazao Liangli Mingpian 波兰乳制品商期待借助中国市场打造亮丽名 片 [Polish dairymen look to make their mark in the Chinese market], Xinhua Daily. Retrieved from: http://www.xinhuanet.com/fortune/2020-11/11/c_1126727704. htm.

Zhu, R.T. (2018, Jun. 25), Dang Bolan Xiju Jiaofu “Zaoyu” Shitiesheng 当“波兰戏 剧教父”遭遇“史铁生” [When the “Godfather of Polish theater” (Lupa) met "Shi Tiesheng”], Southern Metropolis Daily. Retrieved from: https://www.sohu. com/a/237119756_161795. 